\title{
FAKTOR-FAKTOR YANG BERHUBUNGAN DENGAN KEJADIAN KEKURANGAN ENERGI KRONIK (KEK) PADA IBU HAMIL DI WILAYAH KERJA PUSKESMAS SEGINIM BENGKULU SELATAN
}

\section{The Factors Associated with Chronic Energy Deficiency (CED) Incidence in Pregnant Mother in Working Area of Seginim Public Health Center South Bengkulu}

\author{
Liya Lugita Sari ${ }^{1}$ \\ ${ }^{1}$ Program Studi D3 Kebidanan Akademi Kebidanan Manna \\ Email: livalugitasari@gmail.com
}

\section{ARTICLE HISTORY}

Received [20 Juli 2020]

Revised [08 Agustus2020]

Accepted [30 Agustus2020]

\section{KATA KUNCI:}

kejadian KEK, pemeriksaan

kehamilan, pendapatan

keluarga, pengetahuan,

\section{KEYWORDS:}

antenatal care, CED, family income, knowledge

\section{ABSTRAK}

KEK pada ibu hamil dapat mempengaruhi proses pertumbuhan, abortus, Intra Uterin Fetal Death( IUFD), kematian neonatal, cacat bawaan, anemia pada bayi, dan asfiksia intrapartum. Penelitian ini bertujuan untuk mengetahui faktor-faktor yang berhubungan dengan kejadian Kekurangan Energi Kronik (KEK) pada ibu hamil di wilayah kerja Puskesmas Seginim Kabupaten Bengkulu Selatan. Jenis penelitian adalah Deskriptif Analitik dengan desain Cross Sectional. Populasi penelitian adalah seluruh ibu hamil di wilayah kerja Puskesmas Seginim pada bulan Januari-Maret 2020 sebanyak 75 orang. Sampel diambil secara Total Sampling. Pengumpulan data menggunakan data sekunder dan primer. Analisis data menggunakan analisis univariat dan bivariat dengan menggunakan uji statistik Chi-Square dan uji Contigency Coefficient. Hasil penelitian didapatkan sebagian besar ibu hamil berpengetahuan cukup (42,7\%), pendapatan keluarga cukup (69,3\%), pemeriksaan kehamilan tidak teratur (52,0\%) dan tidak KEK (68,0\%). Ada hubungan yang bermakna antara pengetahuan, pendapatan keluarga, dan pemeriksaan kehamilan dengan kejadian KEK dengan keeratan hubungan sedang. Diharapkan kepada tenaga kesehatan untuk mengoptimalkan peran dalam melakukan penyuluhan mengenai KEK.

\section{ABSTRACT}

Cronic Energy Deficiency (CED) in pregnant mother can affect to process of fetal growth, abortion, Intra Uterin Fetal Death (IUFD), neonatal death, congenital defect, infant with anemia, dan intrapartum asfiksia. This Study aimed to know the factors associated with CED incidence in pregnant mother in working area of Seginim Public Health Center South Bengkulu. The type of this study was Descriptif Analytic with Cross Sectional design. The population of this study was all pregnant woment who visited Seginim Public Health Center South Bengkulu in JanuaryMaret 2020 amounted 75 pregnant mothers and the sample technique was Total Sampling. Data collection was used secondary and primer data. Data analysis used univariat and bivariat analysis with Chi-Square and Contingency Coefficient statistical test. The results of this study: 42,7\% pregnant mothers had intermediate knowledge, 69,3\% pregnant mothers had intermediate family income, 52,0\% pregnant mothers did irregular antenatal care, and $68 \%$ pregnant mothers suffered from CED incidence. There was a significant relationship between knowledge, family income, and antenatal care with CED incidence with medium relationship category. It was suggested to health workes to optimize the role in counseling about CED. 


\section{Pendahuluan}

Angka Kematian Ibu (AKI) menjadi salah satu indikator penting dalam derajat kesehatan masyarakat. AKI menggambarkan jumlah wanita yang meninggal dari suatu penyebab kematian terkait dengan gangguan selama masa kehamilan sehingga hal ini menjadi masalah yang besar di Indonesia. Menurut World Health Organization (WHO) sepanjang tahun 2017 sekitar 810 wanita meninggal karena sebab yang dapat dicegah terkait dengan kehamilan dan persalinan, antara 2000 sampai 2017, rasio kematian ibu (jumlah kematian ibu per 100.000 kelahiran hidup) turun sekitar $38 \%$ di seluruh dunia dan $94 \%$ dari semua kematian ibu terjadi di negara berpenghasilan rendah dan menengah (WHO, 2019).

Berdasarkan Profil Kesehatan Indonesia secara umum terjadi penurunan kematian ibu selama periode 1991-2015 dari 390 menjadi 305 per 100.000 kelahiran hidup. AKI di Provinsi Bengkulu dilaporkan sebanyak 137 kasus dengan kasus tertinggi di Kota Bengkulu sebanyak 15 kasus dan terendah di Kabupaten Kaur, Muko-Muko dan Lebong masing-masing 2 kasus. Sementara di Kabupaten Bengkulu Selatan diketahui AKI sebesar 36,7 per 100.000 kelahiran hidup (Dinas Kesehatan Provinsi Bengkulu, 2019).

Kekurangan energi kronik (KEK) yaitu keadaan ibu hamil yang menderita kekurangan makanan yang berlangsung lama (kronik) dengan berbagai timbulnya gangguan kesehatan. KEK pada ibu hamil dapat menyebabkan risiko anemia, pendarahan, berat badan ibu tidak bertambah secara normal, dan serangan penyakit infeksi. Dampak terhadap proses persalinan dapat mengakibatkan persalinan sulit dan lama, persalinan sebelum waktunya (prematur), pendarahan setelah persalinan, serta persalinan dengan operasi cenderung meningkat (Sandjaja, 2009).

Kasus KEK pada ibu hamil salah satunya disebabkan karena adanya ketidak seimbangan asupan gizi (energi dan protein), sehingga zat gizi yang dibutuhkan tubuh tidak tercukupi. Kondisi ini disebabkan karena kurangnya pengetahuan ibu hamil tentang asupan nutrisi yang diperlukan oleh ibu saat hamil (Arisman, 2017). Hasil penelitian Rahayu \& Sagita (2019) menunjukkan bahwa terdapat hubungan antara pendapatan keluarga dengan kejadian KEK pada ibu hamil trimester II di Puskesmas Grogol Kediri.

Upaya pencegahan awal dari faktor risiko kehamilan yaitu dengan pemeriksaan antenatal care (ANC). Menurut WHO, ANC untuk mendeteksi dini terjadinya risiko tinggi terhadap kehamilan dan persalinan juga dapat menurunkan angka kematian ibu dan memantau keadaan janin. Perawatan antenatal umumnya dianggap metode yang efektif untuk meningkatkan hasil kehamilan (Hollowell, 2015).

Survey awal yang peneliti lakukan pada 10 orang ibu hamil TM III di Puskesmas Seginim diketahui 3 orang ibu mengalami KEK, sedangkan 7 lainnya tidak mengalami KEK. Dari ketiga ibu yang mengalami KEK, diperoleh informasi bahwa pendapatan rata-rata keluarga mereka dibawah upah minimun propinsi (UMP), selain itu ibu juga tidak teratur dalam melakukan ANC, dimana ketiganya melakukan ANC hanya di awal kehamilan untuk memastikan kehamilan dan di trimester III karena sudah mendekati proses persalinan.

Berdasarkan wawancara yang dilakukan oleh peneliti kepada 3 ibu hamil yang menderita KEK tentang gizi yang diperlukan ibu selama hamil, ketiganya tidak dapat menjawab tentang apa saja gizi yang diperlukan, berapa banyak asupan yang dibutuhkan tubuh selama hamil, seperti apa jenis makanan yang dibutuhkan dan bagaimana dampaknya bagi ibu hamil jika asupan gizi tidak tercukupi. Ketiganya berasumsi yang penting tidak ada keluhan, dan jika muncul keluhan tinggal datang ke bidan.

Rumusan masalah dalam penelitian ini adalah "Apakah faktor-faktor yang berhubungan dengan KEK pada ibu hamil di wilayah kerja Puskesmas Seginim Bengkulu Selatan?". Tujuan penelitian ini adalah untuk 
mempelajari faktor-faktor yang berhubungan dengan KEK pada ibu hamil di wilayah kerja Puskesmas Seginim Bengkulu Selatan.

\section{Metode penelitian}

Jenis penelitian yang digunakan adalah Deskriptif Analitik dengan desain Cross Sectional. Populasi penelitian ini adalah seluruh ibu hamil di wilayah kerja Puskesmas Seginim bulan Januari-Maret 2020. Teknik pengambilan sampel dilakukan dengan cara Total Sampling. Untuk mengetahui hubungan antara variabel independent dan variabel dependent, digunakan uji statistik Chi-Square $\left(\chi^{2}\right)$ dengan batas kemaknaan $(\alpha=0,05)$ atau confident interval $(\mathrm{CI})=95 \%$. Untuk mengetahui keeratan hubungan, digunakan nilai contingency coefficient (C). Data diolah dengan komputer menggunakan program Stastical Program for Social Science (SPSS).

\section{Hasil Penelitian \\ 1. Analisis Univariat}

Analisis univariat bertujuan untuk mengetahui distribusi frekuensi pengetahuan, pendapatan keluarga, pemeriksaan kehamilan, dan kejadian KEK.

\section{Tabel 1}

Distribusi Frekuensi Pengetahuan Ibu Hamil di Wilayah Kerja Puskesmas Seginim Kabupaten Bengkulu Selatan

\begin{tabular}{|c|c|c|}
\hline Pengetahuan Ibu & Frekuensi & Persentase (\%) \\
\hline Kurang & 23 & 30,7 \\
\hline Cukup & 32 & 42,7 \\
\hline Baik & 20 & 26,7 \\
\hline Total & 75 & 100,0 \\
\hline
\end{tabular}

Berdasarkan Tabel 1 di atas, dapat dilihat bahwa dari $75 \mathrm{ibu}$ hamil, terdapat 23 ibu hamil $(30,7 \%)$ berpengetahuan kurang,
32 ibu hamil $(42,7 \%)$ berpengetahuan cukup, dan 20 ibu hamil $(26,7 \%)$ berpengetahuan baik.

Tabel 2

Distribusi Frekuensi Pendapatan Keluarga di Wilayah Kerja Puskesmas

Seginim Kabupaten Bengkulu Selatan

\begin{tabular}{|c|c|c|}
\hline Pendapatan Keluarga & Frekuensi & Persentase $(\%)$ \\
\hline Rendah & 23 & 30,7 \\
\hline Cukup & 52 & 69,3 \\
\hline Total & 75 & 100,0 \\
\hline
\end{tabular}

Berdasarkan Tabel 2 di atas, dapat dilihat bahwa dari $75 \mathrm{ibu}$ hamil, terdapat 23 ibu hamil $(30,7 \%)$ memiliki pendapatan keluarga rendah dan 52 ibu hamil $(69,3 \%)$ memiliki pendapatan keluarga cukup.

Tabel 3

Distribusi Frekuensi Pemeriksaan Kehamilan di Wilayah kerja

Puskesmas Seginim Kabupaten Bengkulu Selatan

\begin{tabular}{|c|c|c|}
\hline Pemeriksaan Kehamilan & Frekuensi & Persentase $(\%)$ \\
\hline Tidak Teratur & 39 & 52,0 \\
\hline Teratur & 36 & 48,0 \\
\hline Total & 75 & 100,0 \\
\hline
\end{tabular}


Berdasarkan Tabel 3 di atas, dapat dilihat bahwa dari $75 \mathrm{ibu}$ hamil, terdapat 39 ibu hamil $(52,0 \%)$ melakukan pemeriksaan kehamilan tidak teratur dan 36 ibu hamil $(48,0 \%)$ melakukan pemeriksaan kehamilan teratur.

Tabel 4

Distribusi Frekuensi Kejadian KEK di Wilayah Kerja Puskesmas

Seginim Kabupaten Bengkulu Selatan

\begin{tabular}{lcc}
\hline \multicolumn{1}{c}{ Kejadian KEK } & Frekuensi & Persentase (\%) \\
\hline KEK & 24 & 32,0 \\
Tidak KEK & 51 & 68,0 \\
\hline \multicolumn{1}{c}{ Total } & 75 & 100,0 \\
\hline
\end{tabular}

Berdasarkan Tabel 4 di atas, dapat dilihat bahwa dari 75 ibu hamil, terdapat 24 ibu hamil $(32,0 \%)$ mengalami kejadian KEK dan 51 ibu hamil $(68,0 \%)$ tidak mengalami kejadian KEK.

\section{Analisis Bivariat}

Analisis bivariat bertujuan untuk mengetahui hubungan antara pengetahuan, pendapatan keluarga, pemeriksaan kehamilan, dan kejadian KEK.

Tabel 5

Tabulasi Silang Pengetahuan dengan Kejadian KEK di Wilayah Kerja Puskesmas Seginim Kabupaten Bengkulu Selatan

\begin{tabular}{|c|c|c|c|c|c|c|c|c|c|}
\hline \multirow{3}{*}{ Pengetahuan } & \multicolumn{4}{|c|}{ Kejadian KEK } & \multirow{2}{*}{\multicolumn{2}{|c|}{ Total }} & \multirow{3}{*}{$\chi^{2}$} & \multirow{3}{*}{$\mathrm{p}$} & \multirow{3}{*}{$\mathrm{C}$} \\
\hline & \multicolumn{2}{|c|}{ KEK } & \multicolumn{2}{|c|}{ Tidak KEK } & & & & & \\
\hline & $\mathrm{F}$ & $\%$ & $\mathrm{~F}$ & $\%$ & $\mathrm{~F}$ & $\%$ & & & \\
\hline Kurang & 13 & 56,5 & 10 & 43,5 & 23 & 30,6 & \multirow{4}{*}{9,7} & \multirow{4}{*}{0,008} & \multirow{4}{*}{0,339} \\
\hline Cukup & 8 & 25,0 & 24 & 75,0 & 32 & 42,7 & & & \\
\hline Baik & 3 & 15,0 & 17 & 85,0 & 20 & 26,7 & & & \\
\hline Jumlah & 24 & 32,0 & 51 & 68,0 & 75 & 100,0 & & & \\
\hline
\end{tabular}

Tabel 5 memperlihatkan ibu hamil yang mengalami kejadian KEK dan berpengetahuan kurang sebanyak 13 ibu hamil $(56,5 \%)$. Ibu hamil yang tidak mengalami kejadian KEK dan berpengetahuan cukup sebanyak 24 ibu hamil (75,0\%). Hasil uji statistik dengan menggunakan uji Chi-Square $\left(\chi^{2}\right)$, diperoleh hasil nilai $\chi^{2}=9,7>\chi^{2}$ tabel $(5,591)$ dengan nilai $\mathrm{p}=0,008<0,05$.

Tabel 6

Tabulasi Silang Pendapatan Dengan Kejadian KEK di Wilayah Kerja Puskesmas Seginim Kabupaten Bengkulu Selatan

\begin{tabular}{|c|c|c|c|c|c|c|c|c|c|}
\hline \multirow{3}{*}{ Pendapatan } & \multicolumn{4}{|c|}{ Kejadian KEK } & \multirow{2}{*}{\multicolumn{2}{|c|}{ Total }} & \multirow{3}{*}{$\chi^{2}$} & \multirow{3}{*}{$\mathrm{p}$} & \multirow{3}{*}{$\mathrm{C}$} \\
\hline & \multicolumn{2}{|c|}{ KEK } & \multicolumn{2}{|c|}{ Tidak KEK } & & & & & \\
\hline & $\mathrm{F}$ & $\%$ & $\mathrm{~F}$ & $\%$ & $\mathrm{~F}$ & $\%$ & & & \\
\hline Rendah & 16 & 69,6 & 7 & 30,4 & 23 & 30,7 & \multirow{3}{*}{19,0} & \multirow{3}{*}{0,000} & \multirow{3}{*}{0,472} \\
\hline Cukup & 8 & 15,4 & 44 & 86,6 & 32 & 69,3 & & & \\
\hline Jumlah & 24 & 32,0 & 51 & 68,0 & 75 & 100,0 & & & \\
\hline
\end{tabular}

Tabel 6 memperlihatkan ibu hamil yang mengalami kejadian KEK dan berpendapatan rendah sebanyak $16 \mathrm{ibu}$ hamil
$(69,6 \%)$. Ibu hamil yang tidak mengalami kejadian KEK dan berpendapatan cukup sebanyak 44 ibu hamil $(86,6 \%)$. Hasil uji 
statistik dengan menggunakan uji Chi- $>\chi^{2}$ tabel $(3,481)$ dengan nilai $\mathrm{p}=$ Square $\left(\chi^{2}\right)$, diperoleh hasil nilai $\chi^{2}=(19,0) \quad 0,000<0,05$.

Tabel 7

Tabulasi Silang Pemeriksaan Kehamilan (ANC) dengan Kejadian KEK di Wilayah Kerja Puskesmas Seginim Kabupaten Bengkulu Selatan

\begin{tabular}{|c|c|c|c|c|c|c|c|c|c|}
\hline \multirow{3}{*}{$\begin{array}{c}\text { Pemeriksaan } \\
\text { Kehamilan }\end{array}$} & \multicolumn{4}{|c|}{ Kejadian KEK } & \multirow{2}{*}{\multicolumn{2}{|c|}{ Total }} & \multirow{3}{*}{$\chi^{2}$} & \multirow{3}{*}{$\mathrm{p}$} & \multirow{3}{*}{$\mathrm{C}$} \\
\hline & \multicolumn{2}{|c|}{ KEK } & \multicolumn{2}{|c|}{ Tidak KEK } & & & & & \\
\hline & $\mathrm{F}$ & $\%$ & $\mathrm{~F}$ & $\%$ & $\mathrm{~F}$ & $\%$ & & & \\
\hline Tidak Teratur & 22 & 56,4 & 17 & 43,6 & 39 & 52,0 & & & \\
\hline Teratur & 2 & 5,6 & 34 & 94,4 & 36 & 48,0 & 19,9 & 0,000 & 0,478 \\
\hline Jumlah & 24 & 32,0 & 51 & 68,0 & 75 & 100,0 & & & \\
\hline
\end{tabular}

Tabel 7 memperlihatkan ibu hamil yang mengalami kejadian KEK dan melakukan pemeriksaan kehamilan tidak teratur sebanyak 22 ibu hamil $(56,4 \%)$. Ibu hamil yang tidak mengalami kejadian KEK dan melakukan pemeriksaa kehamilan teratur sebanyak $34 \mathrm{ibu}$ hamil $(94,4 \%)$. Hasil uji statistik dengan menggunakan uji ChiSquare $\left(\chi^{2}\right)$, diperoleh hasil nilai $\chi^{2}$ hitung $(19,9)>\chi^{2}$ tabel $(3,481)$ dengan nilai $\mathrm{p}=$ $0,000<0,05$.

\section{Pembahasan}

Berdasarkan hasil penelitian sebagian besar ibu hamil berpengetahuan kurang dan mengalami kejadian KEK sebesar 56,5\% dan ibu hamil yang berpengetahuan baik dan tidak mengalami kejadian KEK sebesar 85,0\%. Hasil uji statistik dengan menggunakan uji Chi-Square $\left(\chi^{2}\right)$ menunjukkan bahwa terdapat hubungan yang bermakna antara pengetahuan ibu hamil dengan kejadian KEK di wilayah kerja Puskesmas Seginim Kabupaten Bengkulu Selatan dengan keeratan hubungan sedang.

Penelitian ini sejalan dengan penelitian yang dilakukan oleh Widyawati (2017) yang menunjukan bahwa ada hubungan yang bermakna antara pengetahuan tentang gizi dengan kejadian KEK. Hasil penelitian ini juga sejalan dengan teori yang dikemukakan Notoatmodjo (2014) yang menyatakan bahwa pengetahuan merupakan salah satu faktor predisposisi (disposing factors) yang mempengaruhi perilaku kesehatan seseorang.
Pengetahuan yang berhubungan dengan masalah kesehatan akan mempengaruhi status kesehatan seseorang. Jika seseorang memiliki pengetahuan yang cukup khususnya tentang kesehatan, seseorang dapat mengetahui berbagai macam gangguan kesehatan yang memungkinkan timbul sehingga dapat dicari pemecahannya. Kurangnya pengetahuan tentang KEK dan cara pencegahannya akan mengakibatkan berkurangnya kemampuan untuk menerapkan informasi dalam kehidupan sehari-hari yang merupakan salah satu penyebab terjadinya KEK pada ibu hamil.

Hasil penelitian menunjukkan bahwa ibu yang berpendapatan rendah dan mengalami kejadian KEK sebesar 69,6\%. Ibu hamil yang tidak mengalami kejadian KEK dan berpendapatan cukup sebesar 86,6\%. Hasil uji statistik dengan menggunakan uji Chi-Square $\left(\chi^{2}\right)$ menunjukkan bahwa terdapat hubungan yang bermakna antara pendapatan keluarga dengan kejadian KEK di wilayah kerja Puskesmas Seginim Kabupaten Bengkulu Selatan dengan dengan keeratan hubungan sedang.

Hasil penelitian ini sejalan dengan penelitian yang dilakukan Rahayu \& Sagita (2019) yang menyatakan bahwa terdapat hubungan antara pendapatan keluarga dengan kejadian KEK pada ibu hamil di Puskesmas Grogol Kediri. Hasil penelitian juga sejalan dengan teori Suhardjo (2015) yang menyatakan bahwa pada umumnya,jika 
tingkat pendapatan naik, maka jumlah makanan yang dimakan cenderung membaik juga. Secara tidak langsung zat gizi tubuh akan terpenuhi dan akan meningkatkan status gizi, dengan demikian maka ibu hamil dapat terhindar dari kejadian KEK.

Hasil penelitian menunjukkan bahwa ibu yang melakukan pemeriksaan kehamilan tidak teratur dan mengalami kejadian KEK sebesar $56,4 \%$. Ibu hamil yang melakukan pemeriksaa kehamilan teratur dan tidak mengalami kejadian KEK sebesar 94,4\%. Hasil uji statistik menunjukkan bahwa terdapat hubungan yang bermakna antara pemeriksaan kehamilan dengan kejadian KEK di wilayah kerja Puskesmas Seginim Kabupaten Bengkulu Selatan dengan keeratan hubungan sedang.

Hasil penelitian ini sejalan dengan teori Revina (2019) yang menyebutkan bahwa pada ibu hamil, antenatal care dapat mengurangi komplikasi kehamilan dan juga mengobati komplikasi secara dini yang akan mempengaruhi kehamilan, Dengan melakukan antenatal care, maka tanda bahaya dapat diinformasikan dari gejala yang ditemui sehingga pengobatan dapat membantu mengurangi pengaruh negatif pada ibu dan janin.

\section{Kesimpulan}

1. Sebagian besar ibu hamil berpengetahuan cukup yaitu sebanyak 32 ibu hamil $(42,7 \%)$

2. Sebagian besar ibu hamil memiliki pendapatan keluarga cukup yaitu sebanyak 52 ibu hamil $(69,3 \%)$.

3. Sebagian besar ibu hamil melakukan pemeriksaan kehamilan (ANC) tidak teratur yaitu sebanyak 39 ibu hamil $(52,0 \%)$.

4. Sebagian besar ibu hamil tidak mengalami kejadian KEK yaitu sebanyak 51 ibu hamil $(68,0 \%)$.

5. Terdapat hubungan yang bermakna antara pengetahuan ibu dengan kejadian KEK di wilayah kerja Puskesmas Seginim Kabupaten Bengkulu Selatan dengan kategori hubungan sedang.
6. Terdapat hubungan yang bermakna antara pendapatan keluarga dengan kejadian KEK di wilayah kerja Puskesmas Seginim Kabupaten Bengkulu Selatan dengan kategori hubungan sedang.

7. Terdapat hubungan yang bermakna antara pemeriksaan kehamilan dengan kejadian KEK di wilayah kerja Puskesmas Seginim Kabupaten Bengkulu Selatan dengan kategori hubungan sedang.

\section{Daftar Pustaka}

Arisman. (2017). Gizi dalam Daur Kehidupan. Jakarta : Kedokteran EGC.

Dinas Kesehatan Provinsi Bengkulu. (2019). Profil Kesehatan Provinsi Bengkulu. Bengkulu : Dinas Kesehatan Provinsi Bengkulu.

Hollowell. (2015). Perawatan Antenatal Care. Jakarta : Yayasan Bina Pustaka Notoatmodjo.(2014). Kesehatan Masyarakat Ilmu dan Seni. Jakrta: Rineka Cipta

Rahayu, D. T., \& Sagita, Y. D. (2019). Pola Makan dan Pendapatan Keluarga dengan Kejadian Kekurangan Energi Kronik (KEK) pada Ibu Hamil Trimester II. Holistik Jurnal Kesehatan, 13 (1) : 7-18. Diunduh dari

http://ejurnalmalahayati.ac.id/index.p $\mathrm{hp} /$ holistik/article/view/847/pdf.

Revina, P. (2019). Manfaat Antenatal Care (ANC) Bagi Ibu Hamil. Diunduh dari: https://www.indonesiana.id/. Diakses 4 April 2020.

Sandjaja, (2009). Risiko Kurang Energi Kronis (KEK) pada Ibu Hamil di Indonesia. Gizi Indonesia, 32(2) : 128-138. Diunduh dari : http://download.garuda.ristekdikti.go. id/article.php?article $=887926$.

Suhardjo. (2015). Perencanaan Pangan dan Gizi. Jakarta : Bumi Aksara.

WHO, (2019). Maternal Maternity. Online. Diakses dari https://www.who.int. tanggal 30 Oktober 2019. 
Jurnal Sains Kesehatan Vol. 27 No. 1 April 2020

Widyawati. (2017). Hubungan antara Pengetahuan tentang Gizi Ibu dan Anak Balita di Daerah Rawan Pangan Kecamatan Tanjung Beringin Kabupaten Serdang Berdagai. Skripsi. Medan : USU 